\title{
George MousouraKis*
}

\section{Legal Transplants and Legal Development: A Jurisprudential and Comparative Law Approach}

\begin{abstract}
The changes in the legal universe that have been taking place in the last few decades have increased the potential value of different kinds of comparative law information and thereby urged new objectives for the comparative law community. The comparative method, which was earlier applied in the traditional framework of domestic law, is now being adapted to the new needs created by the ongoing globalization process, becoming broader and more comprehensive with respect to both its scope and goals. Associated with this development is a growing interest in the question of transferability or transplantability of legal norms and institutions across different cultures, especially in so far as current legal integration and harmonization processes require reasonably transferable models. This paper critically examines the issue of transferability of laws with particular attention to the theory of legal transplants propounded by Professor Alan Watson, one of the most influential contemporary comparatists and legal historians. It is submitted that the element of relativity imposed by the special relationship of the law to its socio-cultural environment must be taken into consideration when the comparative method is applied. However, the view held by some scholars that legal transplants are impossible betrays an exaggeration of cultural diversity as it contradicts the teachings of history and is at odds with recent trends towards legal integration in certain world regions.
\end{abstract}

Keywords: comparative law, legal transplants, legal borrowing, legal change, families of law

\section{Introductory}

At a time when our world society is increasingly mobile and legal life is internationalized, the role of comparative law is gaining importance. While the growing interest in foreign legal systems may well be attributed to the dramatic increase in international transactions, this empirical parameter to the growth of comparative legal studies accounts for only part of the explanation. The other part, at least equally important, is the expectation of obtaining a deeper understanding of one's own legal system through the study and comparison of legal norms, institutions and principles found in foreign systems. Besides providing the jurist with a much broader knowledge of the possible range of solutions to legal problems than the study of a single legal order would present, comparative law gives the jurist an opportunity to fathom the interaction of different disciplines and to connect these to the development and operation of legal rules, for example, when one considers the interface between law and history. Historical analyses of law utilizing the comparative method are essential for the further development of law today. Without the knowledge derived from historical-comparative studies it is impossible to investigate contemporary legal institutions, as these are to a considerable extent the product of historical conditions and mutual influences of legal systems in the past. Moreover, comparative legal studies have performed valuable services in empirically testing the propositions of legal theory. ${ }^{1}$ These propositions

* Professor of Law, University of Auckland, Faculty of Law, Private Bag 92019, Auckland Mail Centre, Auckland 1142, New Zealand.

E-mail: g.mousourakis@auckland.ac.nz

1 Lawson, F. H.: The Comparison: Selected Essays. Amsterdam, 1977, II, 59. 
can be tested on the grounds of concrete comparative material, for there exists a dialectical relationship between theory and practice that extends beyond the narrow limits of a single legal culture-indeed, most legal theorists seem to assume a deductive universality of analysis. As Paton pointed out, it is impossible to comprehend jurisprudence without comparative law, since all schools of jurisprudence (whether historical, philosophical, sociological or analytical) rely on the comparative method. ${ }^{2}$

One type of interest pertaining to knowledge and explanation in comparative law is associated with the traditional comparison de lege lata and/or de lege ferenda. Pursuant to this comparison are searches for models (both conceptual and substantial) for the interpretation of current law, or for the formulation and implementation of legal policy. In today's complex society the lawmaker is often faced with difficult problems. Instead of guessing possible solutions and risking less appropriate results, a lawmaker can draw on the enormous wealth of legal experience by the study of foreign laws. As Rudolf Jhering once remarked, “[T]he reception of a foreign legal institution is not a matter of nationality, but a matter of usefulness and need. No one bothers to fetch a thing from afar when one has one as good or better at home, but only a fool would refuse a good medicine just because it did not grow in his own back garden." 3 It is thus not surprising that legislators, when considering different possible approaches to resolving a particular problem, often take into account how the same (or a similar) problem is dealt with in other jurisdictions. Indeed, contemporary law-making and law-reform in many countries is characterized by a sort of eclecticism. This takes the form of using comparative law to investigate legal approaches and solutions to socio-economic problems, even if the countries whose laws are studied do not belong to the same broader legal family as that of the country concerned. Of course, whenever a proposal is put forward to adopt a foreign legal rule, a legislator must first consider whether the rule has proved efficient in its country of origin when dealing with the specific problem at hand and then, second, whether it will produce the desired effects in the country contemplating its adoption. In many cases it may prove impossible to adopt, without important modifications, a rule that was successful in a foreign country because of differences pertaining, for example, to the court system and the legal process, as well as the more general differences regarding the socio-economic, political and cultural environment in which the rule would have to fit.

Another type of interest in comparative law is connected with the goal of legal unification, or at least harmonization and cooperation at a transnational or international level. ${ }^{4}$ An important aspect to the idea of legal unification relates to the development of supra-national organizations, or the aim of diminishing the traditional relations between state power and the legal regulation of society. Projects aimed at the unification or harmonization of laws are designed to reduce or eradicate, as far as possible and desirable, the discrepancies and inconsistencies between national legal systems by inducing them to adopt common legal rules and practices. In pursuance of this objective, uniform rules are

2 Paton, G.: A Textbook of Jurisprudence. Oxford, 1972. 41.

${ }^{3}$ Geist des römischen Rechts. I, 9th ed. 1955, 8 f; quoted in Zweigert, K.-Kötz, H.: An Introduction to Comparative Law. Oxford, 1987. 16.

${ }^{4}$ It should be noted that whilst legal unification contemplates the substitution of two or more legal systems with one single system, the aim of harmonization is to "effect an approximation or coordination of different legal provisions or systems by eliminating major differences and creating minimum requirements or standards”. Kamba, W. J.: Comparative Law: A Theoretical Framework. International and Comparative Law Quarterly, 23 (1974) 485, at 501. 
often drawn up on the basis of work by experts in comparative law that are then incorporated in transnational or international treaties obliging the parties, as a matter of international law, to adopt the uniform rules as part of their domestic law. Despite the difficulties arising in connection with unification or harmonization efforts, there have been some notable successes, especially within countries that closely cooperate with each other, such as the member countries of the European Union, ${ }^{5}$ and within certain areas of law, such as international commercial law, transportation law, intellectual property law and the law of negotiable instruments. In general, legal unification or harmonisation is sought to be achieved through the use of international institutions. Such institutions include the International Institute for the Unification of Private Law in Rome (UNIDROIT); ${ }^{6}$ the UN

${ }^{5}$ K. Zweigert and H. Kötz assert that harmonisation, at least at a European level, is a desirable political objective with respect to which comparative law is an essential starting-point. They draw attention, in particular, to the role of comparative law as a tool for the development of a private law common to the whole of Europe. According to these authors: "The advantage of unified law is that it makes international legal business easier. In the area they cover, unified laws avoid the hazards of applying private international law and foreign substantive law. Unified law thus reduces the legal risks of international business, and thereby gives relief both to the businessman who plans the venture and to the judge who has to resolve the disputes to which it gives rise. Thus unified law promotes greater legal predictability and security” (An Introduction to Comparative Law, 1998. 16, 25). A notable step in this direction was taken in 1989, when the European Parliament adopted a resolution stating its long-term goal to develop a uniform European Code of Private Law (Resolution A2159/89 of the European Parliament on action to bring into line the private law of the Member States, [1989] OJ C158/400). Furthermore, during the last three decades, several groups of academic lawyers from throughout Europe have been engaged in projects concerned with the harmonization of law in various fields of European private law. In this connection reference should be made to the Principles of European Contract Law, a work of several European academics working in an independent capacity (the Commission on European Contract Law or 'the Lando Commission') (see Principles of European Contract Law, Parts I and II Revised 2000, Part III 2003); the Study Group on a European Civil Code (the successor to the Lando Commission), which prepared several volumes of the Principles of European Law; the Acquis Group, focusing on the systematic arrangement of current Community law with a view to elucidating the common structures of the emerging Community private law; the Common Core of European Private Law Project, which has completed several important comparative studies on on European private law; the Academy of European Private Lawyers ('The Gandolfi Project'), which has published a draft European Contract Code inspired by the Italian Civil Code, and a draft Contract Code prepared for the Law Commissions of England and Scotland; the European Group on Tort Law, which has drafted the Principles of European Tort Law; and the Commission on European Family Law, which carries out research concerned with the harmonization of family law in Europe. On the issue of harmonization with respect to European private law see also Taupitz, J.: Europäische Privatrechtsvereinheitlichung heute und morgen.Tübingen, 1993.

6 The UNIDROIT is an independent intergovernmental organization concerned with the harmonization and coordination of private and especially commercial law between states and the formulation of uniform instruments, principles and rules to attain these goals. It was established in 1926 as an auxiliary organ of the League of Nations; after the League's demise, it was re-established in 1940 on the basis of a multilateral agreement (the UNIDROIT Statute). Achievements include: the Convention relating to a Uniform Law on the Formation of Contracts for the International Sale of Goods (The Hague, 1964); the Convention relating to a Uniform Law on the International Sale of Goods (The Hague, 1964); the Convention providing a Uniform Law on the Form of an International Will (Washington, 1973); the Convention on Agency in the International Sale of Goods (Geneva, 1983); the UNIDROIT Convention on International Financial Leasing (Ottawa, 1988); the UNIDROIT 
Commission on International Trade Law (UNCITRAL); ${ }^{7}$ the European Committee on Legal Cooperation; ${ }^{8}$ the Hague Conference on Private International Law ${ }^{9}$ the World Intellectual Property Organization (WIPO); ${ }^{10}$ the International Labour Organisation; ${ }^{11}$ the Comité

Convention on Stolen or Illegally Exported Cultural Objects (Rome, 1995); the UNIDROIT Model Law on Leasing (2008); and the UNIDROIT Convention on Substantive Rules for Intermediated Securities (2009).

7 This is the core legal body of the UN systems in the field of international trade law. In establishing the Commission, the UN General Assembly recognized that disparities in national laws governing international trade created obstacles to the flow of trade, and it regarded the Commission as the vehicle by which the United Nations could play a more active role in reducing or removing these obstacles. The focus of UNCITRAL's work is the modernization and harmonization of rules on international commercial transactions. Achievements include: the Convention on Contracts for the International Sale of Goods (1980); the Model Law on International Credit Transfers (1992); the Model Law on International Commercial Conciliation (2002); and the Model Law on International Commercial Arbitration (1985-amended 2006).

8 The European Committee on Legal Cooperation (CDCJ) is an inter-governmental body concerned with the standard-setting activities of the Council of Europe in the field of public and private law. It promotes law reform and cooperation in fields of administrative law, civil law, data protection, family law, information technology and law, justice and the rule of law, nationality, refugees and asylum seekers. The Committee carries out its tasks through the adoption of draft conventions, agreements, protocols or recommendations; the organization and supervision of colloquies and conferences; and the monitoring of the implementation and functioning of international instruments coming within its field of competence. Recent achievements include: the Council of Europe Convention on the Protection of Children against Sexual Exploitation and Sexual Abuse (2007); and the European Convention on the Adoption of Children (revised, 2008).

9 The Hague Conference on Private International law is an intergovernmental organization concerned with the progressive unification of the rules of private international law. The principal method used to achieve this purpose consists in the negotiation and drafting of multilateral treaties or Conventions in the various fields of private international law (international judicial and administrative cooperation; conflict of laws for contracts, torts, maintenance obligations, status and protection of children, relations between spouses, wills and estates or trusts; recognition of companies; jurisdiction and enforcement of foreign judgments). Notable achievements include: the Convention on the International Recovery of Child Support and Other Forms of Family Maintenance (2007); the Convention on Choice of Court Agreements (2005); the Convention on Jurisdiction, Applicable Law, Recognition, Enforcement and Co-operation in Respect of Parental Responsibility and Measures for the Protection of Children (1996); the Convention on Protection of Children and Co-operation in Respect of Inter-country Adoption (1993); the Convention of on the Law Applicable to Contracts for the International Sale of Goods (1986); and the Convention on International Access to Justice (1980).

10 The World Intellectual Property Organization is a United Nations agency dedicated to developing an international intellectual property system. It seeks to: harmonize national intellectual property legislation and procedures; provide services for international applications for industrial property rights; provide legal and technical assistance to countries; and facilitate the resolution of private intellectual property disputes.

11 The International Labour Organisation is a UN specialized agency which seeks to bring together governments, employers and workers to set labour standards, develop policies and devise programmes. It carries out its work through three main bodies (The International Labour Conference, the Governing Body and the Office), which comprise governments', employers' and workers' representatives. 
Maritime International; ${ }^{12}$ and the International Civil Aviation Organization (ICAO). ${ }^{13}$ The current interest in matters concerning legal unification and harmonization is connected with the phenomenon of globalization-a phenomenon precipitated by the rapid rise of transnational law, the growing interdependence of national legal systems and the emergence of a large-scale transnational legal practice.

Globalization intensifies the need for a revival of general jurisprudence and a rethinking of comparative law from a global perspective. Rethinking comparative law will involve all of the main tasks of legal theory including synthesis, the construction and elucidation of concepts, the development of theories, both empirical and normative, and the critical analysis of assumptions and presuppositions underpinning legal discourse. Legal scholars pursuing this agenda will often benefit from the learning methods, strategies and techniques of other disciplines. Political science, economics, sociology, history and anthropology, for example, are each likely to provide insights that will assist the study of how institutions and communities influence the development of legal rules. In particular, there is room for a great deal of work on the question of transferability of legal models across different cultures, especially in so far as legal integration and harmonization require reasonably transferable models. In this respect, the need for understanding cultural diversity in a world driven by trends toward global law becomes increasingly important. The point here is that law is more than simply a body of rules or institutions; it is also a social practice within a legal community. It is this social practice that shapes the actual meaning of the rules and institutions, their relative weight, and the way they are implemented and operate in society. But law is not an isolated social practice; it is an aspect of the broader culture to which it belongs. Understanding law presupposes knowledge of the social practice of the legal community and this, in turn, implies familiarity with the general culture of the society in which the legal community is a part. ${ }^{14}$ The relationship between law and culture is

12 This non-governmental organisation is concerned with maritime law and related commercial practices; its object is to contribute to the unification of maritime law in all its aspects.

${ }^{13}$ The ICAO is a UN Specialized Agency seeking to promote secure and sustainable development of civil aviation through cooperation amongst its member States. The charter of ICAO is the Convention on International Civil Aviation, drawn up in Chicago in December 1944, and to which each ICAO Contracting State is a party.

14 According to one definition, culture is a system of symbolic meaning with features distinctive to a society or a social group that forms the basic, common model for the beliefs, values and opinions held by its members. Each society, based on the historical experience of the people in question, chooses a set of meanings especially significant and fundamental for it and systematizes them, thus producing its culture. This symbolic system forms a basic framework for cognition and evaluation for the society's members, and is preserved and transmitted through the processes of socialization. Members of society internalize this framework and then gradually develop their own values, attitudes, beliefs and opinions based on it. In the sphere of law, culture manifests itself in the concept of law, and more generally in the notion of social order prevalent in a society. See Jaeger, G.-Selznick, P.: A Normative Theory of Culture. American Sociological Review, 29 (1964), 653. 'Legal culture' is a multi-dimensional term, which is employed in sociological and anthropological studies of law. Several definitions of legal culture are found in the relevant literature. E. Blankenburg and F. Bruinsma, for example, define legal culture in terms of the interplay of all four levels of legal phenomena: law in the books; the institutional infrastructure (judicial system and legal profession); patterns of legally relevant behaviour (e.g. legal transactions); and legal consciousness. See Dutch Legal Culture (Deventer-Boston, 1991. 8-9). According to L. M. Friedman, legal culture consists of the "attitudes, values and opinions held in society relating to legal system or legal processes”. See Law and Society: 
characterized by continual interaction and interdependence. One might say that law is an element of the culture of a society that both impacts upon culture and is permeated by it. ${ }^{15}$ The legal systems and respective cultures of the world do not exist in isolation from one another, but often contribute to one another through the exchange of information, ideas and models. The more intense and pervasive forms of communication today have engendered more permeable boundaries of the legal systems than at any time in the past.

\section{Legal Transplants and Reception of Laws}

Comparative legal scholarship has an extensive tradition of categorizing systems of law into transnational legal traditions or families of kinship and descent. The division of legal systems into transnational traditions or families fosters the comparative study of law as it allows one to examine legal systems from the viewpoint of their general characteristics, style or orientation. Apart from its practical importance, the division of legal systems into broader families has great value to legal theory, as it requires a more spherical or comprehensive knowledge of law as a general social phenomenon. The problem of classifying legal systems into families has been the subject of discussion among scholars from as early as the beginning of the twentieth century. Although the proposed classifications were revised in light of developments in Russia and other Eastern European nations in recent years, the traditional conceptual framework of legal families remains relevant for describing legal reality in the world today. According to a theory of classification proposed by Arminjon, Nolde and Wolff, ${ }^{16}$ there exist in the world certain 'model' or 'core' systems whose legal rules and institutional structures were directly transplanted (often through military conquest or colonization) or adopted (by virtue of their perceived quality and prestige) in many countries around the world. For these authors, the crucial criterion for the classification of legal systems is the substantive content of laws; and this requires attention to originality, derivation, and common elements, rather than to external factors, such as race or geography. ${ }^{17}$ Another well-known theory of classification has been advanced by Zweigert. Zweigert's proposed criterion for the grouping of legal systems into families is 'style' (Rechtsstil), a multi-faceted or multi-dimensional criterion shaped by the interaction of the following factors: a) the historical background and development of a particular system; b) its predominant and characteristic mode of legal thinking; c) its distinctive legal institutions; d) the hierarchy and interpretation of its legal sources; and e) the ideological background of the system. ${ }^{18}$ It should be mentioned, however, that the borderlines between the various

An Introduction. Englewood Cliffs, N. J., 1977. 103. Elsewhere Friedman refers to legal culture as the "ideas, values, expectations and attitudes towards law and legal institutions which some public or some part of the public holds”. "The Concept of Legal Culture: a Reply”. Nelken (ed.): Comparing Legal Cultures, Dartmouth, Vt., 1997. Legal culture may be seen as embodying two aspects: an 'external' (lay) and an 'internal' (professional). Legal culture, like societal culture in general, is a result of historical evolution. The current state of a legal culture is always between tradition and innovation.

15 See on this Mayer, M. E.: Rechtsnormen und Kulturnormen. Breslau, 1903. 24; Fezer, K. H.: Teilhabe und Verantwortung. Munich, 1986. 22.

16 Arminjon, P.-Nolde, B.-Wolff, M.: Traité de droit compare. Vol. 1, Paris, 1950. 47 ff.

17 Seven 'core' systems and respective legal families are identified by these authors: the French, German, Scandinavian, English, Russian, Islamic and Hindu.

18 On this basis he divided the legal systems of the world into eight groups or families: the 
legal families identified by comparatist scholars are not always clear, and thus it is sometimes difficult to identify with certainty which family a legal system belongs to. Special difficulties are presented by the classification of the so-called 'mixed' or 'hybrid' legal systems, that is, systems whose development has been influenced by two or more legal families. ${ }^{19}$ Moreover, the legal systems of many countries in Asia and Africa constitute a mixture of traditional local law, religious elements and the law imported from European countries during the colonial period or in more recent times. ${ }^{20}$

A great deal of the similarities that exist among legal systems belonging to the same broader legal family or transnational tradition are the result of 'legal borrowing' or 'legal transplanting'. 'Legal transplanting' involves a legal system incorporating a legal rule, institution or doctrine adopted from another legal system. It may also pertain to the reception of an entire legal system, which may occur in a centralist way. To understand the reception of foreign law phenomenon one must examine the historical reasons behind the introduction of foreign law in a particular case, e.g. whether it is the result of conquest, colonial expansion or the political influence of the state whose law is adopted. Territorial expansion through military conquest did not always entail the imposition of the conquering peoples' laws on the subjugated populations. For example, in lands under Roman, Germanic and Islamic rule subject populations continued to be governed by their own systems of law under the so-called 'principle of the personality of law'. In some cases a direct imposition did in fact occur, as happened, for instance, with the introduction of Spanish law in South America. In other cases the law of the conquering nation was introduced in part or in an indirect fashion. For example, during the British and French colonial expansion there was a tendency to introduce into the colonies elements of the legal systems of the colonial powers or to develop systems of law adapted to local circumstances but largely reflecting the character of the metropolitan systems. Furthermore, one should recognize that the process of legal transplanting might be interrupted, or precipitated, by revolutionary change. A revolution may be defined as an historical event that may change the identity of a sociopolitical system by altering the ideological foundations of its legitimacy and, consequently,

Romanistic; the Germanic; the Nordic; the English; the socialist; the Far Eastern; the Islamic; and the Hindu. K. Zweigert: Zur Lehre von den Rechtskreisen. 20th Century Comparative and Conflicts Law. Legal Essays in Honor of Hessel E. Yntema. Leyden, 1961. 45 ff; see also Zweigert, K.-Kötz, H.: An Introduction to Comparative Law. 2nd ed., Oxford, 1987. 68-75.

19 This category embodies the legal systems of Québec (French and English influence); Louisiana (French and American influence); and South Africa (Roman-Dutch and English influence). See Zweigert-Kötz.: op. cit. 119 ff, 240 ff.

${ }^{20}$ Questions have arisen as to whether East Asian legal systems can be grouped into one legal family. A number of scholars, including Zweigert and Kötz, list the People's Republic of China, Japan, Korea and Indo-China as members of the "Far Eastern Family". They argue that the old Chinese doctrines of Confucius, which emphasise social, group or community harmony rather than individual interests, have been very influential in all these societies, with the consequence that individuals tend to avoid litigation in favour of compromise and conciliation. Their classification of the East Asian legal systems into one legal family is thus entirely based on what they regard as a common culture. However, culture is not the only basis on which the problem of classification of legal systems may be resolved. Consider Japanese law, for instance. The Japanese legal system has been variously classified as part of the "Far Eastern" legal family, described as a "civil law" system based on German law, and treated as a "unique hybrid of different legal systems". These different approaches to the classification of one legal system suggest that the classification process is more arbitrary, subjective and open to manipulation than many traditional comparatists recognize. 
its orientation. A revolutionary legitimacy change is the most radical change that a sociopolitical system may undergo. ${ }^{21}$ The transformation of a country's legal system prompted by such a change may entail the system of law moving further away from or closer to other systems, so far as ideological differences and similarities with respect to different countries' socio-political and economic structure are expressed in law. ${ }^{22}$

As commentators have observed, the perceived quality and prestige of the donor system plays a central part in a legal reception process. Consider, for instance, the reception of Roman law in Europe and its admirable longevity as a system under different socioeconomic conditions. Roman law, as preserved by the compilers of Justinian's codification in the sixth century $\mathrm{AD}$, was one of the strongest formative forces in the development of Western legal culture. It was adopted and applied in most of continental Europe during the Middle Ages and the Renaissance (in wide areas of Germany and other European regions it remained an immediate source of law until the end of the nineteenth century). Roman law was received in Catholic, Calvinist and Lutheran countries; it operated in countries where agriculture dominated economic life and it also applied in mercantile centres and later in countries undergoing the industrialization process. This system of law, first adopted in Europe, was directly or indirectly (through a European law code) transplanted in South America, Quebec, Louisiana and many countries in Asia and Africa. But why was Roman law adopted? The medieval reception of Roman law was partly due to the lack of centralized governments and developed formal legal systems that could compete with the comprehensive inheritance of Rome; and partly due to the fact that the lands formerly governed by the Romans were accustomed to this style of thought, and accorded it wisdom and authority. A third feature, deriving almost completely from the model of the Roman Corpus Iuris Civilis, was the desire of the emerging nation-states to codify their laws and the aspirations of later jurists to conform their studies to this model. The important point here is that Roman law was not adopted merely because it was admired, nor because its norms were particularly suitable for the social conditions in the early European nation-states. In fact, many norms of Roman law were entirely antiquated. Foremost, it was the perceived superiority of Roman law as a system that led to the adoption of its norms, even if this adoption was supported by a learned tradition that endured for centuries. ${ }^{23}$ Thus, as an important common denominator

${ }^{21}$ Legitimacy is the quality of a socio-political system that explains its authority at a particular place and time over a particular community. A system's legitimacy may be founded on social consensus (democracies), or on a variety of other elements, such as transcendental command (e.g. theocratic states) or, even, arbitrary oppression. In turn, orientation may vary from old-fashioned, open-ended laissez-faire orientations to communism and many other distinct combinations. Efficiency is a quality that refers to the overall performance of a system. A system develops and remains the same to the extent that the foundation of its legitimacy and the direction of its orientation remain stable. Non-revolutionary changes are under legitimacy control. In such a case, since the foundation of legitimacy is not affected, a change in the direction of orientation must satisfy the criteria of the established legitimacy foundation. Revolutionary change may be the result of a catastrophic collapse with respect to the authority or efficiency of a system.

22 On the role of revolution as a factor explaining the divergence or convergence of legal systems see Rodière, R.: Introduction au droit compare. Paris, 1979. 21.

${ }^{23}$ Seen as constituting an expression of natural reason, Roman law was received in Europe not by virtue of any theory concerning its continued validity as part of the positive law, but in consequence of its own inherent worth. In other words, its validity was accepted not ratione auctoritatis, but auctoritate rationis. 
of Western legal experience, the conceptual system of Roman law may be said to be an apt tertium comparationis-a common basis of the legally organized relationships of life. ${ }^{24}$

Nowadays, foreign rules or doctrines are usually 'borrowed' in the context of legal practice itself, because they fill a gap or meet a particular need in the importing country. As already noted, one of the chief objectives of comparative law has traditionally been the systematic study of foreign laws with the view to deriving models that would assist the formulation and implementation of the legislative policies of states. In drafting or revising statutes and law codes, national legislators often rely on large-scale legislative comparisons that they themselves undertake or mandate. A legislator's readiness to adopt a foreign legal rule is often associated with considerations of economic efficiency. According to Mattei, the reception of foreign legal rules is usually the end result of a competition where each legal system provides different rules for the resolution of a specific problem. ${ }^{25}$ In a market of a legal culture, where rule suppliers are concerned with satisfying demand, ultimately the most efficient rule will be the winner. ${ }^{26}$ Moreover, the study of foreign laws can also be valuable when courts and other authorities interpret and apply the legal rules of their own legal system. In so far as a judge, in filling a gap in the law, is expected to decide in the way in which the legislator would have decided, then the question is: how does a modern legislator reach their decisions? As already noted, a legislator often reaches their decisions by taking into account information about foreign systems provided by comparatists. It is thus unsurprising that judges often seek to justify their decisions by pointing to the fact that a similar approach has been adopted in other jurisdictions. ${ }^{27}$ This is especially true when a

${ }^{24}$ Legal relationships are to a large extent organized by forms derived from Roman law (such as contractus and bona fides). One might say that these forms constitute a kind of pre-knowledge for Western legal systems.

25 See Mattei, U.: Efficiency in Legal Transplants: An Essay in Comparative Law and Economics. International Review of Law and Economics, 14 (1994), 93 ff; Mattei, U.-Pulitini, F.: A Competitive Model of Legal Rules. In: Breton, A. et al. (eds): The Competitive State. Dordrecht, 1991. 207 ff. According to Mattei, from the viewpoint of a particular legal system, 'efficient' is whatever makes the legal system work better by lowering transaction costs. Mattei's approach, which represents an example of the more recent trend to combine comparative law and economics, may be taken to constitute a narrower version of functionalism focusing not on social functions in general but on a particular function, namely the efficiency of a legal rule or institution in economic terms.

${ }^{26}$ But, as Mattei recognizes, the existence of differences between legal systems does not necessarily imply inefficiency. Different legal systems may adopt alternative solutions for the same legal problem, which are neutral as far as the issue of efficiency is concerned.

27 For example, the question whether 'immaterial damages' should be awarded in cases involving infringement of privacy, which was not addressed by the German Civil Code, was answered in the affirmative by the highest German civil and constitutional courts after consideration of foreign law (BGH 5 March 1963, BGHZ 39, 124 and BVerfG 14 February 1973, BVerfGE 34, 269). Furthermore, the German Supreme Court determined that statements made by a person accused of an offence during a police interview were not admissible as evidence if the accused had not been informed of his right to remain silent and of his right to legal representation. The Court drew support for its decision from the American case of Miranda v. Arizona of 1966 as well as from English, French and Dutch law (BGH [1992] Neue Juristische Wochenschrift 1463). In addressing the question of whether land rights should be given to aboriginals the High Court of Australia made extensive references to other legal systems, citing fourteen cases in favour of its decision, only three of which were Australian [High Court of Australia, Mabo \& Others v. State of Queensland (1992) 107 ALR 1]. Similarly, the Supreme Court of Canada referred extensively to foreign, in particular American, case 
judge interprets and applies rules that have been borrowed from other legal systems, as well as the rules introduced as a result of international unification or harmonization of law. ${ }^{28}$ As

law when deciding which rights aboriginal people should have (Inter alia in Van der Peet $v$. The Queen (1996) 2 SCR 507). In Fairchild v. Glenhaven Funeral Services the English House of Lords departed from the normal rules concerning causation in a case where a person suffering from a disease caused by exposure to asbestos would be unable to show which of several employers had caused his condition. Besides relying on common law authority, the House referred to legal sources from France, Germany, Norway and the Netherlands ([2003] 1 AC 32). The list of pertinent examples could easily be extended.

${ }^{28}$ With the exception of the United States, where there is considerable resistance to the influence of foreign sources in the domestic legal system, in Common law countries the exchange of legal ideas at the judicial level is generally encouraged and cross-citations between common law courts in different jurisdictions are frequent. In these countries, the principal criterion for the selection of foreign judgments is legal family and thus the sources most often referred to come from Common law systems. The accessibility of the relevant legal materials with respect to language and availability provides a further reason for judges to consider such sources first. To a lesser extent, a foreign court's standing and prestige can supply an additional reason for judges to take this court's case law into account. In this respect, judges sometimes refer to judgments of the highest courts in Germany, France, Italy and the Netherlands. See on this Mak, E.: Why Do Dutch and UK Judges Cite Foreign Law? Cambridge Law Journal, 70 (2011) 2, 420 ff. As compared with courts in Common law jurisdictions, courts in Continental European or Civil law countries are generally reluctant to look for inspiration outside their national legal framework. This can be explained by reference to differences between the respective legal cultures as regards the style of judicial reasoning and process of decisionmaking. The style of judicial reasoning that prevails in Common law countries allows judges to express their personal socio-political views freely and utilize teleological (consequentialist) arguments-including arguments derived from comparative law-to buttress their legal conclusions. On the other hand, the deductive method of judicial reasoning that predominates in Civil law jurisdictions leaves little room for judges to look beyond their own law into foreign systems for justification of their decisions. Civil law judges do not create their own legal constructions, but borrow them from legal science. It is therefore largely through legal science and legal scholarship that foreign law is brought to their attention. It is important to note, however, that considerable differences prevail between Continental European legal systems as regards the way in which national courts approach foreign law. In Germany it is not uncommon for the highest court to utilize foreign legal sources to support its arguments, even though the number of cases in which this actually happens is rather limited. Furthermore, the use of such sources in judicial deliberations largely concerns references to jurisdictions with a shared legal heritage, such as Switzerland and Austria, while there are only a few cases in which French, Italian, English and American law is cited. The situation in France is very different. In French case law there are hardly any references to foreign legal sources. This is unsurprising, as the decisions of the French Supreme Court (Cour de Cassation) in particular are not extensively reason and often do not even include references to French legal doctrine or case law. The same holds for Belgium, the Netherlands and Greece, where the sparse references to foreign law are only in the most general terms. However, one should be careful not to draw the conclusion that foreign legal sources have no relevance at all to judicial decision-making in these countries. In Continental European countries which have a system of Advocates-General advising the Supreme Court, it is in the opinion of that official that one often finds comparative references to foreign and international statutory and case law. When the court makes an explicit reference to the part of the Advocate-General's opinion containing references to foreign legal sources, an influence of foreign law becomes evident. Consider on this issue Drobnig, U.: The Use of Comparative Law by Courts. In: Drobnig, U.-van Erp, S. (eds): The Use of Comparative Law by Courts. The Hague, 1999. It should be noted, finally, that despite the differences that exist between European countries as regards the use 
the above discussion suggests, a study of legal borrowing must also address the roles that the legal profession, legal science and legal education play in the reception process; the form of the imported law (whether it is a written, customary or judge-made); and whether (or to what extent) the importing and exporting countries are compatible with respect to culture, socio-political structure and level of economic development.

The destinies of legal transplants in diverse cultural, socio-economic and political contexts are important to examine for determining the desirability and applicability of such transplants for legislative and judicial practice. It may be true that ethno-cultural, political and socio-economic differences between the exporting and the importing countries do not necessarily preclude the successful transplantation of legal rules and institutions. Legal rules can be taken out of context and can serve as a model for legal development in a very different society. However, one should keep in mind that an imported legal norm is occasionally ascribed a different, local meaning, when it is rapidly indigenized on account of the host culture's inherent integrative capacity. It is not surprising that, very often, Western legal concepts, institutions and rules imported by non-Western countries are understood in a way that is different from that in the donor countries. The absence of substantial differences in the wording of a statute law between a donor and a host country does not imply that legal reality, or everyday legal and social practice in the two countries, should be identical or similar. The legal reality in the host country may be very different with respect to the way people (including judges and state officials) read, interpret and justify the relevant law and the court decisions based on it. Moreover, the role of statute law in the recipient country may be much weaker than it is in the exporting country and custom may be a predominant factor. Thus, in practice, social rules might effectively prevent people from initiating a legal claim or even using a court decision supporting such a claim. As this suggests, it is not good sense to use the perspective and framework of one's own legal culture when examining a legal rule or institution borrowed by a legal system operating within the context of another culture. ${ }^{29}$ Such an approach carries the risk of implying the existence of many more similarities than there actually are. ${ }^{30}$

of foreign and comparative law, a certain degree of convergence can currently be observed with respect to the national judicial treatment of the European Court of Human Rights and EU law. See on this matter Martinico, G.-Pollicino, O. (eds): The National Judicial Treatment of the ECHR and EU Laws: A Comparative Constitutional Perspective. Groningen, 2010.

${ }^{29}$ See on this Kahn-Freund, O.: On Uses and Misuses of Comparative Law. Modern Law Review, 37 (1974) 1, 1.

30 As A. Watson has remarked, "except where the systems are closely related, the differences in legal values may be so extreme as to render virtually meaningless the discovery that systems have the same or a different rule”. Legal Transplants, 2nd ed., Athens, Georgia, 1993. 5. For example, consider the difficulties surrounding the interpretation of the concept of individual freedom, as found in international treaties on human rights. Individual freedom has a rather different meaning in China and other Asian countries, as compared to the Western view, not just because of a political ideology currently or formerly imposed by the rulers of those countries, but because of a more basic, culturally embedded ideology that originates from a very different, collectivist world view. And see Ewald, W.: Comparative Jurisprudence (II): The Logic of Legal Transplants. American Journal of Comparative Law, 43 (1995), 489. 


\section{Legal Transplants and Legal Development: Watson's Theory Revisited}

Since the publication of the first edition of his seminal book, Legal Transplants: An Approach to Comparative Law in 1974, Professor Alan Watson has produced many works on the relationship between law and society, and the factors accounting for legal change. ${ }^{31}$ In these works he iterates his belief that changes in a legal system are due to legal transplants: the transfer of legal rules and institutions from one legal system to another. According to Watson, the nomadic character or rules proves that the idea of a close relationship between law and society is a fallacy. ${ }^{32}$ Law is largely autonomous and develops by transplantation, not because some rule was the inevitable consequence of the social structure, but because those who control law-making were aware of the foreign rule and recognised the apparent benefits that could derive from it. ${ }^{33}$ Watson does not contemplate that rules are borrowed without alteration or modification; rather, he indicates that voluntary transplants would nearly always-always in the case of a major transplant-involve a change in the law largely unconnected with particular factors operating within society. ${ }^{34}$ Neither does Watson expect that a rule, once transplanted, will operate in exactly the same way it did in the country of its origin. Against this background, Watson argues that comparative law, construed as a distinct intellectual discipline, should be concerned with the study of the historical relationships between legal orders and the destinies of legal transplants in different countries. ${ }^{35}$ On this basis one may identify the factors explaining the change or immutability of law. ${ }^{36}$ Watson asserts that comparative law (which he distinguishes from a knowledge of

${ }^{31}$ See, e.g. Watson, A.: Aspects of Reception of Law. American Journal of Comparative Law, 44 (1996), 335; Comparative Law and Legal Change. Cambridge Law Journal, 37 (1978), 313; Legal Transplants and Law Reform. Law Quarterly Review, 92 (1976) 79; Society and Legal Change. Edinburgh, 1977; 2nd ed., Philadelphia, 2001; Sources of Law, Legal Change, and Ambiguity. Philadelphia, 1984; The Evolution of Law, Oxford, 1985; Legal Origins and Legal Change, London, 1991; The Evolution of Western Private Law, Baltimore, 2001. And see Sacco, R.: Legal Formants: A Dynamic Approach to Comparative Law. American Journal of Comparative Law, 39 (1991), 1 and 343.

32 Legal Transplants, supra note 19, 108.

33 Comparative Law and Legal Change. 37 (2) Cambridge Law Journal, 37 (1978) 2, 313, 31315 and 32.

34 Watson has identified a number of factors that determine which rules will be borrowed, including: (a) accessibility (this pertains to the question of whether the rule is in writing, in a form that is easily found and understood, and readily available); (b) habit (once a system is used as a quarry, it will be borrowed from again, and the more it is borrowed from, the more the right thing to do is to borrow from that system, even when the rule that is taken is not necessarily appropriate; (c) chance (e.g. a particular written source may be present in a particular library at a particular time, or lawyers from one country may train in, and become familiar with the law of another country); and (d) the authority and the prestige of the legal system from which rules are borrowed.

${ }^{35}$ Legal Transplants, supra note 19, p. 6.

36 Ibid. 21. To illustrate his point, Watson mentions a set of rules concerned with matrimonial property, which travelled "from the Visigoths to become the law of the Iberian Peninsula in general, migrating then from Spain to California, [and] from California to other states in the western United States." (Ibid. at 108) He adds, that if one considers a range of legal systems over a long term "the picture that emerge[s] is of continual massive borrowing ... of rules." (Ibid. at 107) On this basis he concludes that the moving of a rule or a system of law from one country to another has now been shown to be the most fertile source of legal development, since "most changes in most systems are the result of borrowing." (Ibid. at 94). 
foreign law) can enable those engaged in law reform to better understand their historical role and tasks. It can provide them with a clearer perspective as to whether and to what extent it is reasonable to appropriate from other systems and which systems to select; and whether it is possible to accept foreign legal rules and institutions with or without modifications. ${ }^{37}$

The concept of transplant bias is an essential element of Watson's theory that legal change primarily occurs through the appropriation or imitation of norms. It refers to a system's receptivity to a particular foreign law as a matter distinct from acceptance based on a thorough assessment of all possible alternatives. ${ }^{38}$ This receptivity varies from system to system and its extent depends on factors such as the linguistic tradition shared with a potential donor system; the general prestige of the possible donor system; and the educational background and experience of the legal professionals in the recipient system. The adoption of an entire foreign legal code is probably the clearest manifestation of transplant bias. According to Watson, juristic doctrine is particularly susceptible to foreign influence. ${ }^{39}$ Precedent, on the other hand, seems to be least affected by transplant biaswhen judges borrow from foreign legal systems, the value of the foreign rule for the judge's own system is often carefully considered and evaluated. Transplant bias involves an authoritative argument that takes, for example, the form: norm $\mathrm{N}$ is a Roman law normRoman law is superior-therefore, norm N should be accepted. Behind the minor premise of this inference there is no general appraisal of all norms of Roman law, but rather an opinion based upon the systematical coherence of the relevant norm. The assertion, 'Roman law is superior', is neither deductive (i.e. based upon an axiom concerning the superiority of Roman law) nor inductive (where one should present reasons for considering the particular norm N good); rather it is quasi-inductive and systematical.

The experience of the legal historian underlies Watson's scepticism towards the view that law is directly derived from social conditions. According to him, history shows that legal change in European private law has occurred mainly by transplantation of legal rules and is not necessarily due to the impact of social structures. He sees legal change as an essentially 'internal' process, ${ }^{40}$ in the sense that sociological influences on legal development are considered generally unimportant. The evidence to support this position is derived from history, which Watson claims to show: that the transplanting of legal rules between systems is socially easy even when there are great material and cultural differences between the donor and recipient societies; that no area of private law is very resistant to change through foreign influence-contrary to the sociologically oriented argument that culturally rooted

37 Despite the rather far-reaching nature of some of his statements, it is important to observe that Watson has generally confined his studies, and the deriving theory of legal change, to the development of private law in Western countries.

38 Transplant bias may be used to denote, for example, a system's readiness to accept a Roman law norm because the norm is derived from Roman law. As a factor of legal change, transplant bias interracts with a number of other factors: source of law; pressure force; opposition force; law-shaping lawyers; discretion factor; generality factor; inertia; and felt needs. Although these factors pertain primarily to the Western legal tradition, Watson believes that they are valid also outside this sphere. Comparative Law and Legal Change. Cambridge Law Journal, 37 (1978) 2, 313-336.

39 This is evidenced by the fact that the reception of Roman law in Continental Europe first occured in the field of legal science.

${ }^{40}$ He speaks of an 'internal legal logic' or of 'the internal logic of the legal tradition' governing legal development. See Watson, A.: The Evolution of Law. Oxford, 1985. 21-22. 
law is more difficult to change than merely instrumental law; ${ }^{41}$ and that the recipient legal systems require no knowledge of the context of origin and development of the laws received by transplantation from another system. ${ }^{42}$ Social, economic, and political factors affect the shape of the generated law only to the extent they are present in the consciousness of lawmakers, i.e. the group of lawyers and jurists who control the mechanisms of legal change. The lawmakers' awareness of these factors may be heightened by pressure from other parts of society, but even then, the lawmakers' response will be conditioned by the legal tradition: by their learning, expertise and knowledge of law, domestic and foreign. Societal pressure may engender a change in the law, but the resulting legal rule will usually be adopted from a system known to the lawmaker and often modified without always a full consideration of the local conditions. Watson stresses that law is, to a large extent, a phenomenon operating at the level of ideology; it is an autonomous discipline largely resistant to influences beyond the law itself. From this point of view, he argues that the law itself provides the impetus for change. ${ }^{43}$ At the same time, he recognizes that there is a necessary relationship between law and society, notwithstanding that a considerable disharmony tends to exist between the best rule that the society envisages for itself and the rule that it actually has. The task of legal theory with comparative law as the starting-point is to shed light on this relationship and, in particular, to elucidate the inconsistencies between the law actually in force and the ideal law, i.e. the law that would correspond to the demands of society or its dominant strata. ${ }^{44}$

Watson's work on the concepts of legal transplants and legal change calls into question the notion that law is a local phenomenon functionally connected with the living conditions

41 See on this Levy, E.: The Reception of Highly Developed Legal Systems by Peoples of Different Cultures. Washington Law Review, 25 (1950), 233.

42 Watson, A.: Legal Transplants and Law Reform. Law Quarterly Review, 92 (1976) 79, 80-81.

43 From the viewpoint of the autopoiesis theory, G. Teubner criticizes Watson for placing too much emphasis on the lawyers' professional practices as such. Teubner argues that these practices are not, in themselves, the motor of legal change but rather the necessary outcome of law's character as a distinctive discourse concerned chiefly with producing decisions that define what is legal. Because what is legal is law's essential focus as an independent discourse, law cannot be governed by social developments of the kind sociologists are concerned with. It may react to these developments but it always does so in its own normative terms. Thus, what Watson sees as the autonomous law development by legal elites, proponents of autopoiesis theory regard as the working out of law's independent evolution as a highly specialized and functionally distinctive communication system. For a closer look see in general Luhmann, N.: Social Systems. 1995; Teubner, G.: Law as an Autopoietic System, 1993; Priban, J.-Nelken D. (eds): Law's New Boundaries: The Consequences of Legal Autopoiesis, 2001. On the implications of the autopoiesis theory for comparative law see Teubner, G.: Legal Irritants: Good Fath in British Law or How Unifying Law Ends Up in New Divergences. Modern Law Review, 61 (1998), 11.

${ }^{44}$ According to Watson, "It should be obvious that law exists and flourishes at the level of idea, and is part of culture. As culture it opeates in at least three spheres of differing size, one within another. ... The spheres are: the population at large, lawyers and lawmakers. By 'lawmakers' I mean the members of that elite group who in a particular society have their hands on the levers of legal change, whether as legislators, judges, or jurists. ... For a rule to become law it must be institutionalized. It must go through the stages required for achieving the status of law. ... Because lawyers and lawmakers are involved in all those processes a rule cannot become law without being subject to legal culture'. Legal Chance: Sources of Law and Legal Culture. University of Pennsylvania Law Review, 131 (1983), 1121, 1152-1153. 
of a particular society. His statement that "legal rules are not peculiarly devised for the particular society in which they now operate" 45 is descriptive rather than normative in nature. It implies that the reception of foreign legal norms and institutions often occurs without the benefit of full familiarity with whatever is adopted in the receiving country. And even when the borrowed rule remains unaltered, its impact in the new socio-cultural setting may be entirely different. ${ }^{46}$ For Watson, the source of the original legal norm or institution does not control the final result of the process of transplantation or borrowing. It is the recipient and not the donor system that has the last word on the mode of application of the imported law. However, as critics have pointed out, Watson's position involves a paradox: if the recipient system controls the outcome of the process initiated by the transplanting, how can one say that foreign models are actually at work in the new local context? ${ }^{47}$ According to Legrand, 'legal transplants' cannot happen, for no rule in the borrowing jurisdiction can have any significance as regards the rule in the jurisdiction from which it is borrowed. This is because, as it crosses borders, the original rule undergoes a change that affects it qua rule. Thus, any approach attributing change in law to the displacement of rules across borders is ill-founded, for it fails to treat rules as actively constituted through the life of interpretive communities. Furthermore, it fails to make apparent the fact that rules are the product of divergent and conflicting interests in society, that is, it eliminates the dimension of power from the equation. In light of the above, Legrand concludes that the shifting complexity of development in the law cannot be adequately explained through a rigid framework such as that furnished by the legal transplants thesis. ${ }^{48}$

In my view, the objections of those critics emphasizing cultural diversity do not militate against the validity of Watson's theory. It may be true that each legal culture is the product of a unique combination of socio-cultural and historical factors. Nevertheless, it is equally true that collective cultural identities are formed through interaction with others and no culture can claim to be entirely original. ${ }^{49}$ There is a degree of uniformity with respect to the emergence of certain needs as societies progress through similar stages of development and a natural tendency exists towards imitation, which may be precipitated by a desire to accelerate progress or pursue common political and socio-economic objectives. ${ }^{50}$ According to del Vecchio, "the basic unity of human spirit makes possible the effective communication between peoples. Law is not only a national phenomenon; it is, first and foremost, a human phenomenon. A people can accept and adopt as its own a law created by another people because, in the nature of both peoples, there exist common demands and needs which [often] find expression in law". ${ }^{1}$ The German comparatist Konrad Zweigert, cites many

${ }^{45}$ Legal Transplants, supra note 19, 96.

46 Id. 116.

47 See Legrand, P.: The Impossibility of Legal Transplants. Maastricht Journal of European and Comparative Law, 4 (1997), 116-120.

48 Ibid. 120.

49 See on this Levi-Strauss, C.: Race et histoire. Paris, 2001. $103 \mathrm{ff}$.

50 On the so-called 'law of imitation' and its role in the evolution of social institutions see Tarde, G.: Les Lois de l'Imitation. Paris, 1890. And see Allen, C. K.: Law in the Making. Oxford, 1964. $101 \mathrm{ff}$.

51 del Vecchio, G.: Les bases du droit comparé et les principes généraux du droit. Revue internationale de droit comparé, 12 (1960), 493, 497. As Albert Hermann Post, one of the founders of the School of Comparative Anthropology (Rechtsethnologie), has remarked "there are general forms of organization lying in human nature as such, which are not linked to specific peoples. ... [F]rom the 
examples from various legal systems, to argue that in 'unpolitical' areas of private law, such as commercial and property transactions and business dealings, the similarities in the substantive contents of legal rules and the practical solutions to which they lead are so significant that one may speak of a 'presumption of similarity' (praesumptio similitudinis). ${ }^{52}$ This presumption, he claims, can serve as a useful tool in the comparative study of different legal systems. ${ }^{53}$ Despite the sheer diversity of cultural traditions in the world today, the problems dogging the regional harmonization of law (e.g. at a European level) and the difficulties surrounding the prospect of convergence of the common and civil law systems, quite a few comparatists today still espouse a universalist approach either through their description of laws or by looking for ways in which legal unification or harmonization at an international or transnational level may be achieved. It is submitted that if it is true that legal rules emanate as a response to social needs (according to the socio-functional view of law), the emergence of a global society will almost inevitably lead to a degree of convergence between different legal systems. ${ }^{54}$

Watson's theory of legal transplants has been subjected to strong criticism by scholars who insist on functional-sociological explanations of law. ${ }^{55}$ However, much of this criticism

forms of the ethical and legal conscience of mankind manifested in the customs of all peoples of the world, I seek to find out what is good and just. ... I take the legal customs of all peoples of the earth as the manifestations of the living legal conscience of mankind as a starting-point of my legal research and then ask, on this basis, what the law is”. Die Grundlagen des Rechts und die Grundzüge seiner Entwicklungsgeschichte: Leitgedanken für den Aufbau einer allgemeinen Rechtswissenschaft auf sociologischer Basis (Schulze, Oldenburg, 1884) XI. According to Post, ["C]omparative-ethnological research seeks to acquire knowledge of the causes of the facts of the life of peoples by assembling identical or similar phenomena, wherever they appear on earth and by drawing conclusions about identical or similar causes”. Bausteine für eine allgemeine Rechtswissenschaft auf vergleichendethnologischer Basis (Schulze, Oldenburg, 1880), citations at 12-13. Other important works of this school include Albert Hermann Post's Einleitung in das Studium der ethnologischen Jurisprudenz, 1886, and Henry Maine’s Ancient Law, 3rd ed., 1866.

52 Zweigert, K.: Des solutions identiques par des voies différentes. Revue internationale de droit comparé, (1966) 1, 5 ff; Zweigert, K.-Kötz, H.: An Introduction to Comparative Law. 2nd ed., Oxford, 1987. 36.

53 It should be noted, however, that Zweigert's thesis has been subjected to strong criticism by somer scholars. See, e.g. Frankenberg, G.: Critical comparisons: Re-thinking comparative law. Harvard International Law Journal, 26 (1985), 411-455. Consider also Legrand, P.: European Systems are not Converging. International and Comparative Law Quarterly, 45 (1996), 52-61.

54 See King, M.: Comparing Legal Cultures in the Quest for Law’s Identity. In: Nelken, D. (ed.): Comparing Legal Cultures. Dartmouth, 1997. 119; Ferrari, V.: Socio-legal Concepts and Their Comparison. In: Oeyen E. (ed.): Comparative Methodology. London, 1990. 63; Markesinis B. (ed.): The Gradual Convergence: Foreign Ideas, Foreign Influences, and English Law on the Eve of the 21st Century. Oxford, 1994; Zimmerman, R.: Common Law and Civil Law, Amerika und Europa-zu diesem Band. In: Zimmerman, R. (ed.): Amerikanische Rechtskultur und europäisches Privatrecht. Tübingen, 1995. 1. For a critical perspective on this issue see Legrand, P.: European Systems are not Converging. International and Comparative Law Quarterly, 45 (1996), 52-61. Some scholars have raised the question of whether or not 'natural convergence' is simply an euphemism for what they refer to as 'Western legal imperialism'. See von Mehren, A. T.: An Academic Tradition for Comparative Law? American Journal of Comparative Law, 19 (1971), 624; Knieper, R.: Rechtsimperialismus. Zeitschrift für Rechtspolitik. 29 (1996), 64.

55 See, e.g. Abel, R.: Law as Lag: Inertia as a Social Theory of Law. Michigan Law Review, 80 (1982), 785; Legrand, P.: What 'Legal Transplant'? In: Nelken, D.-Feest, J. (eds): Adapting Legal 
fails to detect the intellectual roots of Watson's theory and misses the opportunity to evaluate it in the light of its proper background. As already noted, Watson remarks that, as a matter of fact, societies often tolerate much law that has no correspondence with what is 'needed' or regarded as efficient. The thesis that law may be dysfunctional in relation to society lies in the idea of 'survivals'-a key concept of nineteenth and early twentieth century evolutionary anthropology. In his 1871 work on Primitive Culture, E. B. Tylor (often called 'the father of British anthropology"), formulated a comprehensive theory to bridge the gap between the present and the remote past. This was the theory of 'survivals': elements of culture or society that evolution has left behind-irrational, obsolete practices and beliefs that continue past their period of usefulness. Tylor's influential treatment of survivals inspired Oliver Wendell Holmes's analysis of the permanence of legal norms and institutions after the demise of the beliefs, necessities or customs that generated them. ${ }^{56}$ From a functional viewpoint, however, survivals cannot be adequately understood simply by reference to that mental disposition called 'conservativism'. Conservartism itself is in need of explaining and that explanation has to be functional. ${ }^{57}$ Watson's notion of 'inertia' may be useful to consider in this connection. Inertia is defined as the general absence of a sustained interest of society and its ruling elite to struggle for the most socially satisfactory rule. For law to be changed there must exist a sufficiently strong impulse directed through a pressure force operating on a source of law. This impulse must be strong enough to overcome the inertia. But how can inertia be explained? Watson notes that there is a normal desire for stability and society, particularly the dominant elite, have a generalized interest in maintaining the status quo. This reflects an abstract interest in stability, which is linked to the fact that many legal norms have no direct impact on the lives of most citizens. Furthermore, the mystique surrounding law as well as practical considerations may obstruct legal change. For instance, the case may be that anticipated long-term benefits are not sufficient to justify a reform if the costs are not outweighed by the short-term benefits. Legal inertia has, I think, two aspects. First, it renders a 'static' justification of law sufficient: law is justified by past behaviour and behaviour by norms. This kind of inertia is inherent in all legal decision-making that strives to maintain regularity and predictability in the practice of law. Besides this aspect of inertia, inertia also relates to the structure and function of law in society. There are two kinds of structural matters for consideration: (a) law is to a certain extent resistant to certain social change, and society to certain legal change; and (b) there is a 'relative resistance' to change pertaining to the time-lag between different functionally interdependent changes.

We may now proceed to comment on Watson's attempt to explain why the legal rules are quite often borrowed rather than generated by a given society. As previously noted, for Watson much in the law depends upon its 'internal logic'-a logic that is very much that of an elite distancing itself from the rest of society. In the creation of their product, lawyers enjoy a great deal of freedom and legal transplants occur thanks to that freedom. According to

Cultures. Oxford, 2001. 55; Wise, E. M.: The Transplant of Legal Patterns. American Journal of Comparative Law, 38 (1990); Murdock, G. P.: How Culture Changes. In: Shapiro, H. (ed.): Man Culture and Society. New York, 1990. 256. On the view that law is the result of the social needs of a given society see in general W. Friedmann: Law in a Changing Society, 2nd ed., Harmondsworth, 1972; Damaska, M.: The Faces of Justice and State Authorit. New Haven, 1986; Friedman, L. M.: A History of American Law. New York, 1973.

56 See Holmes, O. W.: The Common Law. (ed. by S. M. Novick) Dover, New York, 1991. 5 and 35 (originally published in 1881).

57 Consider on this Barnard, A.: History and Theory in Anthropology. Cambridge, 2000. $158 \mathrm{ff}$. 
Watson, in most areas of law, and in particular within private law, it is not the holders of political power (those who prescribe which persons or bodies create the law and how the validity of the law is assessed) who determine what the relevant rules are or should be. ${ }^{58}$ The study of the activity of the jurisconsults in ancient Rome, of the law professors in Continental Europe and of the English judges clearly demonstrates the importance of legal elites as the real shapers of the law. In Watson's scheme, the discourses of legal elites are largely selfreferential: the members of a professional group, such as lawyers, regard the law as belonging to their (distinct) professional culture. Within this group, authority is derived primarily from reputation. And reputation, in turn, depends on argumentative skill and inventiveness according to the rules of legal reasoning governing legal debates-rules that have implicitly been established by the participants themselves. This is why lawyers claim to be solving legal problems by applying a legal logic peculiar to their own profession. Thus, although lawyers may be involved directly or indirectly in political decisions, their intellectual outlook does not necessarily depend on their political orientation. Many critics failed to grasp the functional character of Watson's explanation as to why lawyers devote so much energy playing self-referential games. His point is that lawyers' activities that apparently do not satisfy any practical need establish and confirm their identity as an elite. The outcome of lawyers' discussions may be arbitrary or may reflect specific power pressures or demands. But even when the result of the process is arbitrary, it can still be explained functionally.

\section{Concluding Remarks}

The starting-point of comparative law is often the appearance of common social problems in different legal orders. The question is whether there are common features or, conversely, differences in their legal regulation within these diverse legal orders. How should these similarities or differences be explained? But the existence of a common social problem is not a sufficient starting-point for comparative law. For a meaningful legal comparison to be undertaken some common features of culture are essential. The element of relativity must be considered when comparative law is used in the search for similarities between different legal systems or relied upon to enhance the understanding of one's own legal system, or employed in the process of harmonizing law. This relativity is imposed by the special relationship of the law to its cultural, political and socio-economic environment and its effect on the meaning and function of legal rules, institutions and principles must be addressed. To the extent that socio-cultural diversity is a reality, law is bound to be defined in diversified terms. However, the view that legal transplants are impossible, as some scholars have asserted, is too extreme and betrays an exaggeration of cultural diversity. To deny the possibility or the desirability of legal transplants contradicts the teachings of history and is at odds with the need for legal integration in certain world regions. What is required is a form of analysis that would be capable of striking the right balance between these, seemingly contradictory, perspectives.

58 "Law is power. Law is politics. Law is politics in the sense that persons who have the political power determine which persons or bodies create the law, how the validity of the law is assessed, and how the legal order is to operate. But one cannot simply deduce from that, as is frequently assumed, that it is the holders of political power who determine what the rules are and what the sources of law are to be”. Watson, A.: Roman Law and Comparative Law. Athens, Georgia, 1991. 97. 